$$
\text { "tmcs-glasnovic" — 2010/11/14 — 22:15 — page } 263 \text { — \#1 }
$$

\title{
The requirements in statistics education - comparison of PISA mathematical tasks and tasks from the mathematical textbooks in the field of statistics
}

\author{
Dubravka Glasnović Gracin and Predrag Vuković
}

\begin{abstract}
This work presents the results of the analysis of both PISA items and Croatian mathematical textbooks in the field of statistics.

The analysis shows that PISA's released statistics problems have in many ways different mathematical requirements from the requirements of textbook problems in the statistics chapters, with respect to the mathematical activities, complexity and in the forms of questions. The textbook analysis shows that mathematical examples and problems often require operation and interpretation skills on a reproductive or connections level. Statistics textbook problems are given in the closed-answer form. The results also show that while PISA puts strong emphasis on the statistics field, in the current Croatian curriculum this field is barely present. These discrepancies in requirements and portion of statistics activities surely affect the results of Croatian pupils on PISA assessment in the field of mathematical literacy.
\end{abstract}

Key words and phrases: teaching statistics, mathematics textbooks, PISA assessment, mathematical requirements, analysis.

ZDM Subject Classification: U20, K40.

\section{Introduction}

From the very beginning of conducting the PISA assessment, the public and educational circles pay a lot of attention on it, in the context of national ranking as well as in commenting PISA theoretical background. PISA (Programme 


$$
\text { "tmcs-glasnovic" — 2010/11/14 — 22:15 — page } 264 \text { — \#2 }
$$

for International Student Assessment) is developed by the OECD participating countries (Organization for Economic Co-operation and Development), it takes place every third year starting with the year 2000 and examines reading literacy, mathematical literacy and scientific literacy among 15-year-old students [8].

"The primary aim of the OECD/PISA assessment is to determine the extent to which young people have acquired the wider knowledge and skills in reading, mathematical and scientific literacy that they will need in adult life." ([8], pp. 7)

In PISA framework mathematical literacy is defined as "individual's capacity to identify and understand the role that mathematics plays in the world, to make well-founded judgments and to use and engage with mathematics in ways that meet the needs of that individual's life as a constructive, concerned and reflective citizen" [8]. In order to properly measure mathematical literacy, in the domain of mathematical literacy three components are distinguished: mathematical contents required for solving problems successfully, mathematical competencies, and mathematical context in which the problems are located ([8], [1]).

Although the particular PISA questions solved by 15-year-old students in PISA assessment are not available for the public, OECD released examples and some items from the past assessments that represent a profile of PISA mathematical problems. Those released problems were already analyzed according to various criteria (e.g. [6], [4]).

The analysis of the published PISA problems according to its mathematical requirements shows that PISA assessment emphasizes mathematical contents in the fields of statistics and functions [4]. Furthermore, PISA problems mostly contain the rich textual mathematical questions which are situated in everyday situations, and which often require interpretations of graphical representations, mostly of functional dependencies or statistical representations. Also, it is required to have skills of modeling problems, interpretation of different mathematical contents, argumentation, and explaining the open-answer problems. One half of the analyzed questions required the competencies of elementary computing and operating, while the other half required modeling, argumentation, representation and interpretation. The required mathematical content and mathematical activities influenced the complexity of particular problems. In the field of mathematical literacy in PISA 2006, 27\% of testing items required reflection skills, which consist of posing complex problems, reasoning, original mathematical approach, generalizations etc. 


$$
\text { "tmcs-glasnovic" — 2010/11/14 — 22:15 — page 265 — \#3 }
$$

International ranking of PISA results and a new concept of theoretical background given in OECD framework caused a big media interest, as well as interest in public and educational circles. Although PISA clearly says that it doesn't measure outcomes in curricular mathematics ([2], [8], pp. 11), national PISA rankings are often related to a success of mathematics education in the particular country. In this paper we determine and discuss the discrepancies between the requirements in obligatory statistics education in Croatia and PISA requirements in the field of statistics within the mathematical literacy. ${ }^{1}$

A possible way to find out the requirements in obligatory statistics education is to analyze the statistical problems from mathematics textbooks. The survey about usage of mathematics textbooks was carried out on a thousand mathematics teachers in Croatia, and it showed that a mathematics textbook is the major authority and plays a central role in the compulsory mathematics education in Croatia [3]. The results show that even 97\% of respondents always or often choose the problems for mathematical exercising from the chosen textbooks during their lessons. Also, $62 \%$ of respondents declared their usage of slightly modified textbook examples during the mathematics classes. Even $99 \%$ of responders always or often give their students homework from the chosen obligatory textbook. Also, more than $90 \%$ of surveyed teachers choose the problems from the textbooks to prepare their students to test examinations, and more than $90 \%$ of responders compose tests in accordance with the problems from the textbooks. These results show that teachers and students in primary mathematics education in Croatia use problems from mathematical textbooks to a great extent. Thus, we analyzed the mathematics textbooks problems according to the same criteria as the analyzed PISA problems, in order to find out the mathematical requirements in mathematics textbooks and to compare them with requirements of PISA assessment.

This work presents the results of the analysis of mathematics textbooks just in the field of statistics. PISA gives a big accent on statistical problems, so it would be interesting to find out the similarities and differences between PISA requirements and textbooks' requirements in the field of statistics education.

\footnotetext{
${ }^{1}$ Authors would like to thank Prof. Dr. Edith Schneider and Prof. Dr. Werner Peschek from the Institut für Didaktik der Mathematik - Austrian Educational Competence Centre, IFF, Alpen-Adria-Universität Klagenfurt for all the helpful suggestions during the preparation of this article.
} 


$$
\text { "tmcs-glasnovic" — 2010/11/14 — 22:15 — page 266 — \#4 }
$$

\section{PISA requirements in the field of statistics}

PISA mathematical literacy is assessed in relation to the mathematical content, mathematical competencies and to the situations in which mathematics is used. The mathematical content is mainly defined in terms of four "big ideas" or "overarching ideas": quantity, space and shape, change and relationships, and uncertainty [8]. The overarching idea of Quantity focuses on our need for quantification in everyday life. It includes the recognition of numerical patterns, an understanding of relative size, measures, representing numbers in various ways, understanding the meaning of operations, mental arithmetic and estimating. The overarching idea of Space and shape includes the understanding of geometrical objects and their relative positions. The overarching idea of Change and relationships includes thinking about relationships, often described or modeled by various mathematical functions. Relationships may be given in a variety of different representations (symbolic, graphical or tabular representation). The especially important and valuable aspect in the field of representations is the translation between different representations.

The PISA overarching idea of Uncertainty includes the topics of data and chance and thus fully covers the areas of statistics and probability. "Specific mathematical concepts and activities that are important in this area are collecting data, data analysis and display/visualization, probability and inference." ([8], pp. 37)

In the analysis of released mathematical PISA 2000 and 2003 problems, 21\% of released problems represented the field of statistics and probability [4]. Moreover, PISA assessment in 2006 gave as much as 17 out of 48 problems that represented the field of uncertainty, which fully covers the field of statistics and probability ([1], pp. 161). This means that in more than one-third of given test items in PISA assessment in 2006, a student needed to apply the knowledge of statistics and probability. "This type of statistical thinking should be used by every individual" ([1], pp. 133).

This leads us to the conclusion that the extent to which PISA emphasizes the idea of Uncertainty, i.e. statistics and probability is remarkable. "Dealing with uncertainty from a mathematical and scientific perspective is essential." ([8], pp. 35) 


$$
\text { "tmcs-glasnovic" — 2010/11/14 — 22:15 — page } 267 \text { — \#5 }
$$

\section{Portion of statistics in PISA and in mathematics education}

Statistics and probability are introduced to Croatian compulsory mathematics education in 2006 as a part of mathematics curriculum of the $7^{\text {th }}$ school grade [7]. According to that curriculum, Croatian students learn both statistics and probability during approximately 8 school hours in their entire compulsory education. The subject mathematics is in Croatia represented with 4 hours a week. This means that students in their eight years of compulsory school have 1120 hours of mathematics lessons. Both statistics and probability classes are therefore represented in about $0.7 \%$ of total mathematics education. Comparing to that, in PISA assessment in 2006 more than a third (35\%) of given test problems belonged to the big idea of uncertainty ([1], pp. 161).

The data given above refer to both statistics and probability, because they match the big idea of Uncertainty in PISA Framework. But solely the statistics is represented with $0.4 \%$ in total mathematics education in Croatia. On the other hand, released PISA 2000 and 2003 items give 5 out of 26 mathematical items from the field of statistics ([9], [10]). These comparisons show discrepancies in the portion of statistics problems in PISA assessment and the portion of statistics in mathematics education in Croatia.

\section{Statistics contents in PISA and in mathematics education}

According to the current curriculum from 2006 ([7], pp. 249), the statistics education encompasses two obligatory themes: the graphical data representations and the arithmetic mean. The aim of the theme Graphical data representations is to create and interpret tables, bar diagrams and circle diagrams. Key terms in this chapter are frequency, relative frequency, tabular representation, bar diagram and circle diagram. The curriculum gives required achievements in this field: to represent collected data in frequency table and in relative frequency table, to represent the data graphically with a bar diagram or a circle diagram. It is also required to interpret the data given in tables, in bar diagrams or circle diagrams. The aim of the theme Arithmetic mean is to introduce the idea of the arithmetic mean by various examples from everyday life and to know how to compute the average from the given data.

The insight into PISA Framework shows that in statistics content PISA requires knowledge in "collecting data, data analysis and display/visualization" ([8], pp. 37). The analysis of released PISA statistics problems shows that 5 


$$
\text { "tmcs-glasnovic" — 2010/11/14 — 22:15 — page 268 — \#6 }
$$

out of 6 statistics problems require basic knowledge in interpreting bar diagrams, one of them requires knowledge about circle diagrams as well, and one PISA item requires understanding the idea of arithmetic mean (Table 1). These content requirements (bar diagram, circle diagram, arithmetic mean) fully match the content requirements from the Croatian curriculum in the field of statistics.

Table 1. Statistics contents in PISA released items

\begin{tabular}{llc}
\hline Item Name & Statistics Content & $\begin{array}{c}\text { Is this content a part of } \\
\text { Croatian Curriculum? }\end{array}$ \\
\hline Robberies, M179Q01 & Bar diagram & Yes \\
Exports, M438Q01 & Bar diagram & Yes \\
Exports, M438Q02 & Bar diagram, Circle diagram & Yes \\
Science Tests, M468Q01 & Arithmetic Mean & Yes \\
Litter, M505Q01 & Bar diagram & Yes \\
Test Scores, M513Q01 & Bar diagram & Yes \\
\hline
\end{tabular}

\section{Comparison of mathematical activities in PISA and in statistics education}

The goal of this research was to analyze the statistics problems from mathematics textbooks and to find out the required students' competencies within the compulsory mathematics education in Croatia. The obtained results have been accordingly compared to the results of the analysis of mathematical requirements in the publicly available PISA items from the field of statistics [4].

The analysis encompassed all the statistics examples and problems from the three most used mathematics textbooks in Croatia in the school year 2006/07. These textbooks were used by $85 \%$ of all the $7^{\text {th }}$ grade pupil population. ${ }^{2}$ In the textbook A there were all together 113 statistics problems to analyze, in the textbook B there were 74 of them, and in the textbook C 116 statistics problems. Textbook problems were analyzed in the same way and according to the same instruments as PISA statistics items [4]. The systematization basis for research is taken from "Bildungsstandards", i.e. the Austrian educational standards for mathematics [5]. Every statistics problem and example in textbook was classified according to required mathematical activities, its complexity and answer type.

${ }^{2}$ In this text the analyzed textbooks are given codes A, B and C. Readers interested in original are invited to contact authors. 


$$
\text { "tmcs-glasnovic" — 2010/11/14 — 22:15 — page } 269 \text { — \#7 }
$$

The mathematical activities field is divided into representations and modeling, calculation and operation, interpretation and argumentation and reasoning $[5]$.

Representation concerns transmission of the given mathematical data into another mathematical representation. For example, it is about transmissions from one statistical representation to another (table, bar diagram, line diagram, circle diagram etc.) Modeling concerns recognizing relevant mathematical relationships from the given situation and representing the same problem in the mathematical mode (symbolic, graphical etc.)

Calculation concerns conducting elementary computation operations with concrete or generalized numbers. Operation concerns concrete, sensible and efficient conducting of computational or constructive steps. It also concerns transforming measure units, transforming mathematical expressions, solving equations, estimating results, approximations and conducting elementary geometrical constructions.

Interpretation concerns recognizing relations and relevant data given in the mathematical representations (graphical, symbolical, and tabular) and their interpretation in the given context. Interpreting includes appropriate reading the graphical or symbolical mathematical representations and their interpretation in the given context.

Argumentation concerns description of mathematical aspects that speak pro or contra some particular decision. It requires concrete and adequate implementation of mathematical relations and characteristics, mathematical rules, as well as a correct usage of mathematical language. Reasoning concerns sequence of true arguments that lead to certain conclusion.

Table 2. Activity requirements in statistics education

\begin{tabular}{lccc}
\hline Activities in Statistics Education & Textbook A & Textbook B & Textbook C \\
\hline Representations and modeling & $32 \%$ & $30 \%$ & $18 \%$ \\
Calculation and operation & $45 \%$ & $50 \%$ & $43 \%$ \\
Interpretation & $23 \%$ & $20 \%$ & $37 \%$ \\
Argumentation and reasoning & $0 \%$ & $0 \%$ & $2 \%$ \\
\hline
\end{tabular}

For each statistics problem we determined the required activities and consequently their total number. Table 2 shows the portion of each activity in the total. For example, in the statistics chapters of the textbook A pupils have to use their interpretation skills in $23 \%$ of all required activities. The results show that the major emphasis in Croatian statistics problems is put on calculation activities 


$$
\text { "tmcs-glasnovic" — 2010/11/14 — 22:15 — page } 270 \text { — \#8 }
$$

(Table 2). This result can be explained with the fact that the main requirement of the statistics content Arithmetic Mean is to compute the average from the given numerical data.

The topic Graphical Data Representations refers to activities of representing and interpreting various data. The results show significant difference between the analyzed textbooks requirements related to drawing graphs and interpreting them. The textbook A and B namely emphasize the activities of drawing diagrams (in about $30 \%$ of all statistics activities), while the textbook $\mathrm{C}$ more emphasizes interpretations of given diagrams (in 37\%). The PISA assessment however puts the strong emphasis on interpretation skills in statistics problems. The interpretation of various bar diagrams is required in 5 out of 6 statistics PISA released problems (Table 3 ).

Table 3. Activities and complexity in PISA released items

\begin{tabular}{|c|c|c|c|}
\hline Item Name & $\begin{array}{l}\text { Mathematical Activities and } \\
\text { Contents }\end{array}$ & Complexity & $\begin{array}{l}\text { Usual for textbook } \\
\text { problems? }\end{array}$ \\
\hline $\begin{array}{l}\text { Robberies, } \\
\text { M179Q01 }\end{array}$ & $\begin{array}{l}\text { Interpretation (of a bar dia- } \\
\text { gram), Argumentation }\end{array}$ & $\begin{array}{l}\text { Reflection } \\
\text { knowledge }\end{array}$ & No \\
\hline $\begin{array}{l}\text { Exports, } \\
\text { M438Q01 }\end{array}$ & $\begin{array}{l}\text { Interpretation (reading the bar } \\
\text { diagram) }\end{array}$ & $\begin{array}{l}\text { Reproduction } \\
\text { knowledge }\end{array}$ & Yes \\
\hline $\begin{array}{l}\text { Exports, } \\
\text { M438Q02 }\end{array}$ & $\begin{array}{l}\text { Interpretation (of a bar and } \\
\text { a circle diagram), Calculation } \\
\text { (percents) }\end{array}$ & $\begin{array}{l}\text { Constructing } \\
\text { connections }\end{array}$ & Yes \\
\hline $\begin{array}{l}\text { Science Tests, } \\
\text { M468Q01 }\end{array}$ & Calculation (arithmetic mean) & $\begin{array}{l}\text { Constructing } \\
\text { connections }\end{array}$ & No \\
\hline $\begin{array}{l}\text { Litter, } \\
\text { M505Q01 }\end{array}$ & $\begin{array}{l}\text { Interpretation (of a table), Rea- } \\
\text { soning }\end{array}$ & $\begin{array}{l}\text { Reflection } \\
\text { knowledge }\end{array}$ & No \\
\hline $\begin{array}{l}\text { Test Scores, } \\
\text { M513Q01 }\end{array}$ & $\begin{array}{l}\text { Interpretation (of a bar dia- } \\
\text { gram), Argumentation }\end{array}$ & $\begin{array}{l}\text { Reflection } \\
\text { knowledge }\end{array}$ & No \\
\hline
\end{tabular}

In all analyzed textbooks we can notice the lack of the problems that require argumentation and reasoning (Table 2). In the textbooks A and B there was not any activity with argumentation or reasoning requirements, and in the textbook $\mathrm{C}$ there is only $2 \%$ of them. On the other hand, in PISA released items, 3 out of 6 statistics problems require argumentation or reasoning activities (Table 3). Also, they are presented in open-answer form. The textbook analysis shows that open answer questions are not represented at all in the textbooks $\mathrm{A}$ and $\mathrm{B}$, and in the textbook $\mathrm{C}$ the open answer problems are represented with 5\%. Closed answer problems are the ones that fully dominate in Croatian statistics education. 


$$
\text { "tmcs-glasnovic" — 2010/11/14 — 22:15 — page } 271 \text { — \#9 }
$$

\section{Comparison of complexity requirements in PISA and in statistics education}

We also find interesting the results of the analyzed textbook problems according to the mathematical complexity. The complexity field concerns three different complexity levels: applying directly basic knowledge and skills, constructing and dealing with connections, and reflecting or applying reflection knowledge.

Table 4. Complexity requirements in statistics education

\begin{tabular}{lccc}
\hline Complexity Requirements in Statistics Education & A & B & C \\
\hline $\begin{array}{l}\text { Applying directly basic knowledge and skills; reproduction } \\
\text { knowledge and skills }\end{array}$ & $69 \%$ & $58 \%$ & $51 \%$ \\
$\begin{array}{l}\text { Constructing and dealing with connections between variety of } \\
\text { terms, theorems, methods and representations }\end{array}$ & $31 \%$ & $39 \%$ & $40 \%$ \\
$\begin{array}{l}\text { Applying reflection knowledge; reflecting on mathematical } \\
\text { ideas that are not directly readable from the given problem }\end{array}$ & $0 \%$ & $3 \%$ & $9 \%$ \\
\hline
\end{tabular}

We determined the complexity of each statistics task. Table 4 shows the portion of each complexity level in the total number of tasks. The results of the textbook analysis show that the statistics problems which require reproduction knowledge dominate in statistics education in Croatia. They are represented with $69 \%$ of analyzed problems in textbook A, with $58 \%$ in textbook B, and with $51 \%$ in the textbook C (Table 4). In PISA analyzed items only one problem required the reproduction knowledge (Table 3 ).

The statistics problems that require building connections between various mathematics activities and ideas are in the textbook A represented with $31 \%$, in the textbook B with $39 \%$ and with $40 \%$ in the textbook C (Table 4). The secondary analyses showed that these problems mostly consist of computing and drawing circle diagrams, or connecting graph interpretations with various computing. These results point that the textbook problems with connections complexity refer to constructing simpler connections between interpretations and computing.

In the analyzed textbooks there is the remarkable deficiency of the problems that require applying reflection knowledge (Table 4). The problems with required reflection knowledge are represented with $0 \%$ and $3 \%$ of analyzed problems in the textbooks A and B. This domination of reproduction knowledge or problems that require simpler connections can be explained with the fact that the Croatian students learn statistical topics for the first time in their schooling, and thus it is necessary to make a good introduction to the statistics and to build the 


$$
\text { "tmcs-glasnovic" — 2010/11/14 — 22:15 — page } 272 \text { — \#10 }
$$

strong base with the collection of easy problems. On the other hand, 13-year-old students are mature enough to deal with more complex statistics problems where the reflection knowledge is required, especially if these problems are authentic or embedded in the interesting contexts. In the analyzed PISA items there are 3 out of 6 problems that require reflection knowledge, all of them with argumentation or reasoning knowledge and given in open answer form. The textbook analysis shows that such problems are not common in the statistics education in Croatia.

\section{Additional results of textbook analysis}

Statistics school themes are particularly appropriate for students' personal engagement in creating statistics representations and problems with authentic contexts. For example, students could create frequency tables with the context closed to their own experiences and environment. It could be a circle diagram which represents the results of some authentic mathematics test, instead of some imaginary test etc. Such authentic situations in statistics may act motivating for students. But the results show that in analyzed textbooks dominate problems with non-authentic contexts. In the textbook $\mathrm{A}$ there are authentic contexts in $18 \%$ and in textbook $\mathrm{B}$ and $\mathrm{C}$ even $0 \%$ and $1 \%$ of all statistics problems and examples (Table 5).

Table 5. Authenticity requirements in statistics education

\begin{tabular}{lccc}
\hline & A & B & C \\
\hline Problems with authentic context in the field of statistics & $18 \%$ & $0 \%$ & $1 \%$ \\
Problems with realistic context, but not authentic (the situation is & $82 \%$ & $100 \%$ & $99 \%$ \\
imaginary, e.g. imaginary class or imaginary test results) & & & \\
\hline
\end{tabular}

Although the mathematics textbooks show some similar results in the given analysis, however they differ between themselves. In the Table 6 the reader can find some more results remarked during the textbooks analysis.

\section{Conclusion}

The results of the analysis of Croatian mathematics textbooks show that the textbook items in the field of statistics differ from the PISA released statistic test items. The present curriculum analysis shows that Croatian students learn 
Table 6. Additional remarks

\begin{tabular}{|c|c|c|c|}
\hline Remarks & Textbook A & Textbook B & Textbook C \\
\hline $\begin{array}{l}\text { Dealing with num- } \\
\text { bers }\end{array}$ & $\begin{array}{l}\text { All the problems } \\
\text { (also from the topic } \\
\text { arithmetic mean) } \\
\text { are given in solely } \\
\text { natural numbers. }\end{array}$ & $\begin{array}{l}\text { The given data } \\
\text { are expressed with } \\
\text { various number } \\
\text { types (naturals, } \\
\text { decimals, negatives, } \\
\text { fractions). }\end{array}$ & $\begin{array}{l}\text { The given data } \\
\text { are expressed } \\
\text { with naturals and } \\
\text { decimals. }\end{array}$ \\
\hline Language & $\begin{array}{l}\text { The language in } \\
\text { analyzed problems } \\
\text { is more typical for } \\
\text { mathematics than } \\
\text { for everyday life. }\end{array}$ & $\begin{array}{l}\text { The language is } \\
\text { extremely typi- } \\
\text { cal for university } \\
\text { mathematics. }\end{array}$ & $\begin{array}{l}\text { The language in } \\
\text { analyzed problems } \\
\text { is close to everyday } \\
\text { life. }\end{array}$ \\
\hline Routine problems & $\begin{array}{l}\text { A lot of routine } \\
\text { problems which dif- } \\
\text { fer from each other } \\
\text { only by context. }\end{array}$ & $\begin{array}{l}\text { Variety of different } \\
\text { problems. }\end{array}$ & $\begin{array}{l}\text { Variety of com- } \\
\text { pletely different } \\
\text { problems. }\end{array}$ \\
\hline $\begin{array}{l}\text { Encourage for gifted } \\
\text { students }\end{array}$ & $\begin{array}{l}\text { In the textbook sec- } \\
\text { tion for gifted stu- } \\
\text { dents there are no } \\
\text { problems from the } \\
\text { field of statistics. }\end{array}$ & $\begin{array}{l}\text { In the textbook sec- } \\
\text { tion for gifted stu- } \\
\text { dents there are no } \\
\text { problems from the } \\
\text { field of statistics. }\end{array}$ & $\begin{array}{l}\text { There isn't any sec- } \\
\text { tion for gifted stu- } \\
\text { dents at all. }\end{array}$ \\
\hline $\begin{array}{l}\text { Organization inside } \\
\text { the textbook and } \\
\text { handling it }\end{array}$ & $\begin{array}{l}\text { The textbook is } \\
\text { clearly arranged, it } \\
\text { is easy to handle for } \\
\text { both the student } \\
\text { and teacher. }\end{array}$ & $\begin{array}{l}\text { The textbook with } \\
\text { examples is sepa- } \\
\text { rated from the the- } \\
\text { ory and exercises } \\
\text { book. }\end{array}$ & $\begin{array}{l}\text { The textbook is } \\
\text { fuzzy arranged; it is } \\
\text { difficult to handle it } \\
\text { (because of the non } \\
\text { logical organization } \\
\text { and settlement } \\
\text { of examples and } \\
\text { problems). }\end{array}$ \\
\hline
\end{tabular}

statistics in the $7^{\text {th }}$ school grade to a very limited extent. The analysis of PISA released problems show that content requirements in the field of statistics match the Croatian curricular themes, such as bar diagram, circle diagram, or arithmetic mean.

The textbook analysis shows that mathematical examples and problems in the field of statistics often require operation and interpretation skills on a reproduction or simpler connections level. Problems are mainly given in the closed answer form. Argumentation and reasoning skills, open answer forms and reflective thinking are not represented to a big extent in mathematics textbooks in statistics education in Croatia. 


$$
\text { "tmcs-glasnovic" — 2010/11/14 — 22:15 — page } 274 \text { — \#12 }
$$

The analysis of the published PISA statistics problems shows that OECD emphasizes the rich textual mathematical questions which often require interpretations of statistical representations, argumentation and reasoning, using the open-answer problems with engaging reflection and connection knowledge. Characteristics of PISA problems do not dominate in the primary mathematics education in Croatia. Those differences surely affect our students' results on the international PISA scale.

The Croatian PISA 2006 working group for mathematics in their report [1] suggests that we should take from the PISA assessment those elements which can bring an improvement to Croatian mathematics education. One of the possible elements which would improve mathematics education is surely more sensitivity and concern for statistics education. It includes bigger portion of statistics in mathematics education (not only in $7^{\text {th }}$ grade), as well as encouraging of argumentation and reasoning skills combined with reflection knowledge and open answer problems.

\section{References}

[1] M. Braš Roth, M. Gregurović, V. Markočić Dekanić and M. Markuš, Prirodoslovne kompetencije za život, Nacionalni centar za vanjsko vrednovanje obrazovanja - PISA centar, Zagreb, 2008.

[2] J. De Lange, PISA - Does it really measure literacy in mathematics?, Fokus Didaktik: Vorträge beim 16. Internationalen Kongress der ÖMG und Jahrestagung der DMF, Universität Klagenfurt, (E. Schneider, ed.), Profil Verlag, 2005.

[3] D. Glasnović Gracin and V. Domović, Upotreba matematičkih udžbenika u nastavi viših razreda osnovne škole, Odgojne znanosti 11, no. 2(18) (2009), 45-65 (in Croatian).

[4] D. Glasnović Gracin, Mathematical Requirements in PISA Assessment, Second International Scientific Colloquium "Mathematics and Children" - How to Teach and Learn Mathematics, Osijek, 2009, 56-61.

[5] Institut für Didaktik der Mathematik - Österreichisches Kompetenzzentrum für Mathematikdidaktik - IFF, Alpen-Adria-Universität Klagenfurt, Standards für die mathematischen Fähigkeiten österreichischer Schülerinnen und Schüler am Ende der 8. Schulstufe, Version 4/07, web, 2007 (in German).

[6] W. Meyerhöfer, Tests im Test: Das Beispiel PISA, Budrich Verlag, 2005 (in German).

[7] MZOŠ, Nastavni plan i program za osnovnu školu, Ministarstvo znanosti, obrazovanja i športa Republike Hrvatske, Zagreb, 2006 (in Croatian). 


$$
\text { "tmcs-glasnovic" — 2010/11/14 — 22:15 — page } 275 \text { — \#13 }
$$

[8] OECD, The PISA 2003 Assessment Framework - Mathematics, Reading, Science and Problem Solving Knowledge and Skills, web, January 2003, www. pisa.oecd.org/dataoecd/46/14/33694881.pdf.

[9] OECD, PISA Released Items - Mathematics, web, June 2006, www. oecd.org/dataoecd/14/10/38709418.pdf.

[10] OECD, Mathematik-Kompetenz. Sammlung aller bei PISA freigegebenen Aufgaben der Haupttests 2000, 2003 und 2006, Projektzentrum für vergleichende Bildungsforschung, Universität Salzburg, Salzburg, 2007.

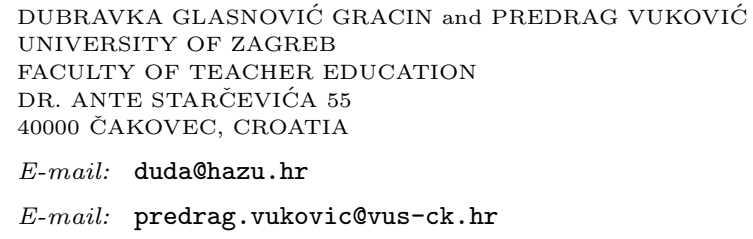

(Received February, 2010) 